Kilian Heck

\title{
BUILDINGS, PORTRAITS AND TREES. THE UNIVERSITY LANDSCAPE OF GREIFSWALD IN POMERANIA
}

Caspar David Friedrich's painting Wiesen bei Greifswald (Meadows near Greifswald), completed between 1820 and 1822, is a strikingly symmetrical composition that depicts the silhouette of the old university city on the Baltic Sea from a distance. ${ }^{1}$ As in a dream, the city's buildings seem to be floating above a slumbering horizon. This impression is intensified by a delicate veil of fog and the muted blue colour of the cloudless sky that rises above the silhouette. The city seems to have been cut off from reality, and shifted to another, far-off and totally otherworldly, dimension. In contrast to all this, the lush meadows and prancing horses in the foreground seem extremely realistic. However, the viewer is still left at a distance, which is accentuated by the shrubbery that crosses from the upper left to the lower right, and acts as a threshold for the eye. It is the contrast between this distanced fictionalisation and the close-up reality that creates the tension in the picture. Although the city is located on the horizon in the distance, some of the buildings are clearly recognisable. In addition to the three main churches, starting

DOI: https://doi.org/10.12697/BJAH.2018.16.01

1 Johannes Grave, Caspar David Friedrich (Munich, London, New York: Prestel, 2012), 35-37, see also: http://www.hamburger-kunsthalle.de/sammlung-online/caspar-davidfriedrich/wiesen-bei-greifswald [accessed 27 August 2017]. 
from the left, St Mary's (Sankt Marien), St Nicholas's (Sankt Nikolai) and St Jacob's (Sankt Jakobi), the roof of the University of Greifswald college building, established in 1456, can be seen to the right of St Jacob's.

For Caspar David Friedrich, it was important that all the buildings be depicted with mimetic precision. Friedrich had learned this detailed technique of drawing decades earlier from his first teacher, Johann Gottfried Quistorp, who was the university's academic drawing instructor and building master. ${ }^{2}$ Around 1790, Friedrich took weekly lessons from Quistorp in the university's academic drawing hall. There the students practiced drawing nature and models. The students were also taught to prepare construction plans and architectural drawings. The fact that Quistorp took his students outdoors to draw the surrounding landscape is proven by the fact that very early plein air drawings (i.e. drawings made outdoors) originate from Greifswald. In 1802, Friedrich portrayed his teacher as a tiny figure with a top hat and pipe lying on a rock viewing the surrounding landscape. Later, Friedrich used the architectural drawing skills he had learned from Quistorp in some of his own architectural sketches, for instance, of churches and grave monuments. ${ }^{3}$

The case of Friedrich and the lessons he took from Quistorp prove that drawing was part of the general academic curriculum at Greifswald during the $18^{\text {th }}$ century. This was true for all subjects at the university. ${ }^{4}$ Quistorp's predecessor as building master - a job that was not given an official title until the $19^{\text {th }}$ century - was Andreas Mayer (1716-1782) from Augsburg, who became Professor of Mathematics and Physics at the university in $1740 .{ }^{5}$ However, Mayer's teaching duties at Greifswald also included cartography, astronomy, meteorology and archaeology. His legacy, still visible today, includes the main building of the university, which was built

2 Dirk Alvermann, 'Johann Gottfried Quistorp (1755-1835)', Die Geburt der Romantik: Friedrich, Runge, Klinkowström (Greifswald: Stiftung Pommersches Landesmuseum, 2010), $43-80$.

3 Grave, Caspar David Friedrich, 108-109.

4 Cf. Wolfgang Kemp, '...Einen wahrhaft bildenden Zeichenunterricht überall einzuführe'. Zeichnen und Zeichenunterricht der Laien 1500-1870 (Bodenheim: Syndikat, 1987).

5 Michael Lissok, 'Architekturausbildung an der Greifswalder Hochschule?', Das steinerne Antlitz der Alma mater. Die Bauten der Universität Greifswald 1456-2006, ed. by Michael Lissok, Bernfried Lichtnau (Berlin: Lukas Verlag, 2006), 46. 
between 1747 and 1759 to replace the old college building - the Ernestinum Ludovicianum - which had been built between 1591 and 1597. ${ }^{6}$ The new building is one of the most significant $18^{\text {th }}$ century university buildings in Germany, and one of the most important structures of Late Baroque architecture in Pomerania. According to Michael Lissok, Mayer had a special interest in construction even before he was appointed to his position. His father had been an architect in the Free Imperial City of Augsburg. ${ }^{7}$ It is not surprising, therefore, that in addition to lectures on mathematics, physics and astronomy, he also lectured on architecture. For instance, courses called Die Regeln der Baukunst (The Rules of Architecture) and Civilbaukunst (Civil Architecture) were offered in 1765/66 and 1777; Die Civil und Kriegsbaukunst (Civil and Military Architecture) in 1777 and Die Fortifikation (Fortification) in 1778. As Michael Lissok has written, Mayer, a mathematician and a polyhistor in the field of natural science with diverse interests, also had multiple qualifications related to the history of architecture, which were useful when it came to designing the main building. ${ }^{8}$ Since the subjects taught by Mayer included arithmetic, geometry, and mechanical sciences, it can be said that he taught subjects that formed the classic basis for an architectural education. ${ }^{9}$

Andreas Mayer was a student of Christian Wolff (1679-1754), the most important German philosopher of the Enlightenment. Wolff recorded his thoughts on architecture in the text Bau-Kunst (Building Art), which was a part of his popular work Anfangs-Gründe Aller Mathematischen Wissenschaften (The Fundamentals of All Mathematical Knowledge) (first edition: Halle, 1710)..$^{10}$ In it, he adheres to the strictly rational teaching of architecture, which was based on mathematical knowledge and used to teach building as a practical science, whereas

6 Torsten Rütz, “"Das schönste ist das akademische Gebäude.” Die Kollegiengebäude der Universität Greifswald', Das steinerne Antlitz der Alma mater. Die Bauten der Universität Greifswald 1456-2006, ed. by Michael Lissok, Bernfried Lichtnau (Berlin: Lukas Verlag, 2006), 34; Lissok, 'Architekturausbildung an der Greifswalder Hochschule?', 46.

7 Lissok, ibidem.

8 Ibidem.

9 Ibidem.

10 Werner Müller, 'Architektur und Mathematik', Architekt und Ingenieur. Baumeister in Krieg und Frieden, ed. by Ulrich Schütte, Hartwig Neumann, Andreas Beyer Ausstellungskataloge der Herzog-August-Bibliothek (Wolfenbüttel: Herzog August Bibliothek Wolfenbüttel, 1984), especially $99 \mathrm{ff}$. 
'beauty' and 'appeal' were clearly emphasised as categories to be associated with architecture. ${ }^{11}$ It can be assumed that the teaching of the subjects related to construction started in 1775 at the latest, and continued until Mayer's death in 1782; and thereafter, Johann Gottfried Quistorp, as the instructor of academic drawing, resumed the teaching of these subjects in $1788 .{ }^{12}$ His classes included the following subjects: Bürgerliche Baukunst (Bourgeois Architecture), Kriegsbauweise (Military Construction Methods) and Landbaukunst (Agrarian Architecture). The classes continued until Quistorp retired in $1826 .{ }^{13}$

The integration of architectural studies and practical architecture, a direct result of the philosophy of the Enlightenment, is clearly visible in the university's main building. The construction of the building, which still adorns the university today, started under Mayer's direction and according to his plans in 1747-1748. Against the wishes of the council, and probably thanks to the strong support of the Swedish state, the work started with the demolition of the central section of the old building. The new college building was consecrated on April 28 of 1750. However, the construction was not completed until the consecration of the instrument hall above the library in $1753 .{ }^{14}$

The three-story building was over 23 axes long and relatively narrow, being only four axes wide. The building was crowned by a mansard roof. The five central axes, behind which a large auditorium was located on the lower floor and a library on the upper floor, were each emphasised by two slightly protruding risalits. These surrounded the three central axes and, on the lower floor, were divided into a colossal order using a pilaster strip on the lower floor and Ionic pilasters on the upper floor. The windows on the lower floor date back to an extension that was completed around 1880. On the second floor, the library - the Alte Aula (Old Assembly Hall) today - extends from the piano nobile to the floor above, which is designed as a mezzanine and includes the library's

\footnotetext{
11 Lissok, 'Architekturausbildung an der Greifswalder Hochschule?', 47.

12 Ibidem.

13 Ibidem, 48.

14 Rütz, “Das schönste ist das akademische Gebäude.” Die Kollegiengebäude der Universität Greifswald', 38 .
} 
balcony. While the Swedish coat of arms located on the northern side of the triangular gable was removed in 1830, the Pomeranian coat of arms on the southern side with 'wild men' on either side has survived above the architrave until the present day. The wings of the main building are relatively modest and not divided by risalits. Both porches on the southern side have narrow stairways, but these were not built until $1830 .{ }^{15}$

Although the form of the main building is reminiscent of a palace, and in literature, allusions have been made to the central structure of Schwerinsburg Palace near Anklam, the Greifswald college building has many details that do not correspond to palace architecture. ${ }^{16}$ Thus, for instance, there is no centrally located main entrance. The portals serve as more of an indication of the building's use. The four narrow stairways also follow this logic and provide access from the side of the building to the auditorium and the central rooms of the two-story library above it. ${ }^{17}$

The positioning of the interior rooms is especially telling: the administrative rooms and professors' living quarters are placed concentrically around the centre comprised of the auditorium and library. The professors' apartments were located on the outer walls of the building, extended three stories up, and were separated from the public space in the middle of the building. ${ }^{18}$ The apartment systems of princely palaces, where the living quarters also flanked the ceremonial rooms, definitely provided the model for this arrangement. In addition, it is also apparent that, at least partially, the building is designed as an enfilade. ${ }^{19}$

Torsten Rütz already noticed that Andreas Mayer, who was born in Augsburg, based the design for the library on monastery libraries of Upper Swabia, for instance, the library hall in the Benedictine

15 Rütz, “Das schönste ist das akademische Gebäude.” Die Kollegiengebäude der Universität Greifswald', 39 .

16 Joachim Fait, 'Die Geschichte des Greifswalder Universitätsbaues', Festschrift zur 500-Jahrfeier der Universität Greifswald, 17.10.1956, ed. by Wilhelm Braun, Ernst Kähler (Magdeburg: Volksstimme, 1956), 169.

17 Cf. Rütz, “"Das schönste ist das akademische Gebäude.” Die Kollegiengebäude der Universität Greifswald', 39.

18 Ibidem, 40.

19 For the rooms and their exact location, see ibidem, $40 \mathrm{ff}$. 
Abbey in Ottobeuren, which was built in $1711-1719 .{ }^{20}$ Ottobeuren is only about 70 kilometres from Augsburg. And it's true that a gallery parapet also exists in Ottobeuren, the ends of which are emphasised by double columns. The balustrade vases at Greifswald, which were designed by the Stralsund sculptor Jacob Frese, are also similar to the ones in Ottobeuren. Frese also created the putti and herms for Greifswald. ${ }^{21}$ However, in Ottobeuren, capitals in Corinthian style were chosen, while the capitals in Greifswald are in the Ionic style. One of the sheets in the set of engravings of Greifswald college building that was published in 1754 depicts a view of the library hall from the east.

Along with the rooms that have already been mentioned, we can see the Naturalien Kammer, which was called the collection of 'Pomeranian objects' in 1774, therefore, a collection of old objects was apparently located in this room. ${ }^{22}$ In addition, on the floor plan, we can see three smaller auditoriums located above each other. The law auditorium was located on the first floor, the philosophy, or small theological auditorium on the second, and the Theatrum Anatomicum on the third floor along with a separate Praeparier Kammer. There was also an instrument hall in the attic. ${ }^{23}$

When assessing the Greifswald college building, the botanic garden complex should not be overlooked. It was established as a Baroque parterre garden, and with the architecture of the college building, it comprises a Baroque palace complex. Two engravings from a series created by Martin Engelbrecht in 1754 provide us with an idea of the garden, which has now been totally destroyed, and which was located on the southern side of the college building. ${ }^{24}$ Two symmetrical garden pavilions stood in front of the main building on the south side, and the floor plans provide a clear indication of their purpose. Among other things, an orangery and the gardener's dwelling were located here. Behind it, to the south, was the botanical garden itself. Along with the acanthus

20 Rütz, “"Das schönste ist das akademische Gebäude.” Die Kollegiengebäude der Universität Greifswald', 42.

21 Ibidem, 41.

22 Ibidem, 40.

23 Ibidem.

24 Cf. Fait, 'Die Geschichte des Greifswalder Universitätsbaues', 168. 
ornamentation of the bosquets, we see flower beds and parterre de broderie, some of which partially recede like volutes and others that are designed as squares. On the central axis, on a slight rise in the rear of the garden, there is a one-room house with a botanical classroom. Behind it, medieval fortifications with a wall, moat and garden, stretched south toward the city.

With its abundant volume, Andreas Mayer's Greifswald college building corresponds totally to the standards of the palaces of its day. The modest architectural ornamentation can be seen as resulting from the strictly rational approach to architecture that Mayer himself taught. However, in the literature, parallels are drawn to the neoclassical Baroque of France, although it can also be found in structures in North and East Germany from an earlier period; for instance, from 1700 to 1730 in the work of Jean de Bodt. ${ }^{25}$ On the other hand, a comparison with Swedish Baroque has yet to be made. In the future, this could produce even more definite results.

The idea that in many of its individual forms, but not all, the Greifswald college building, along with the Baroque garden in front of it, resembles a large rural palace or manor house with its extensive property is supported by the fact that, to a great extent, the financing for the University of Greifswald came from its rural properties. Until the early $20^{\text {th }}$ century, the professors' salaries were paid from the income earned by the Eldena Abbey and district, which the university had acquired from Bogislaw XIV, Duke of Pomerania, in 1634. The university owned a landed estate that totalled over 14,000 hectares, of which a mere 10,000 hectares survived after restitution was made in 1990. However, until 1945, the University of Greifswald was the second largest landowner after Prince Putbus in the Prussian province of Pomerania. Even today, the university is the largest landowner among the universities of Germany. ${ }^{26}$ In addition to the large estate, there were numerous

25 Hans-Joachim Kuke, Jean de Bodt 1670-1745: Architekt und Ingenieur im Zeitalter des Barock (Worms: Wernersche Verlagsanstalt, 2002).

26 Ivo Asmus, 'Die Universität Greifswald als Gutsherrin in der Frühen Neuzeit', Universität und Gesellschaft, vol. 2, ed. by Dirk Alvermann, Karl-Heinz Spiess (Rostock: Hinstorff, 2006), 65-96. 
patronage rights related to the nearby church congregations. ${ }^{27}$ Here, as a footnote, it should be mentioned that in 1835, the Königliche Staats- und landwirtschaftliche Akademie Eldena (Eldena Royal State and Agricultural Academy) was built on the former property of the Eldena Abbey, and it was the first educational institution in Prussia where one could acquire a university education in agriculture combined with practical training. ${ }^{28}$

The architectural picture of the University of Greifswald during the Age of Enlightenment would be incomplete if we did not mention the observatory. In this case as well, the participation of Mayer was the determining factor, because in 1741 he apparently set up an observatory in the house that had been built after his designs at Martin-Luther-Str. 10. Here, Andreas Mayer and Heinrich Lambert Röhl observed the transit of Venus in 1761 and $1769 .{ }^{29}$ The first observatory was built for the university in 1775 near the Fangenturm (Prisoners' Tower) near the Ryck River.

In conclusion, it can be said that the traits typical of a small university of the Enlightenment are present in Greifswald. The university's large college building - the design of the floor plan, the stairways and the facade - clearly show that a strict formal idiom has been chosen. On the one hand, the design is based on Andreas Mayer's architectural teachings, and indirectly on those of his teacher Christian Wolff, and can be considered a prototype for a university of the Enlightenment. On the other hand, it is also based on the strict neoclassical Baroque style that originated in France, as it is encountered in various forms in the Baltic Sea region. However, the college building is also a hybrid because the almost residential country-manor-type building is just as recognisable, along with the adjoining strictly geometrical garden complex that is similar to the properties of the great noble families in the Baltic Sea region. The hybrid nature of the Greifswald college building

27 Dirk Schleinert, 'Die Universität als Kirchenpatron', Universität und Gesellschaft, vol. 2, ed. by Dirk Alvermann, Karl-Heinz Spiess (Rostock: Hinstorff, 2006), 97-134.

28 Michael Lissok, 'Die Königliche staats- und landwirtschaftliche Akademie zu Eldena. Kulturlandschaft im 19. Jahrhundert', see: http:/galerien.stralsunder-akademie.de/2015/schriften/ AKADEMIE-ELDENA-Lissok.pdf [accessed 27 August 2017].

29 See: Tobias Röwf, 'Greifswalder Linsen- und Spiegelteleskop wird 90 Jahre alt (1924-2014)': https://www.uni-greifswald.de/universitaet/einrichtungen/kustodie/wissenschaftlichesammlungen/sammlungsobjekt-des-quartals/greifswalder-sternwarte-mondgloben [accessed 27 August 2017]. 
is also apparent in the way the central library hall is designed as the focal point of the building, a model adopted from the Baroque libraries of Upper Swabia. The engravings by copper engraver Martin Engelbrecht who, like Mayer, was from Augsburg, also tend to depict the sauntering society of the Baroque nobility rather than the university's professors or students. At this point, it would be interesting to read some sociological studies that provide more detail on the university's academic staff and their adoption of the behavioural patterns of the nobility, for instance, in connection with hunting parties, galas and the use of carriages by the professors. The academic riding hall from 1788 could provide evidence of this. However, such supplemental research does not currently exist.

Kilian Heck: Building, Portraits and Trees. The University Landscape of Greifswald in Pomerania

Keywords: University of Greifswald; Pomerania; architecture; UNIVERSITY LANDSCAPE; ENLIGHTENMENT; CAspar DaVid Friedrich; Andreas Mayer

Kilian Heck is Professor of Art History at the University of Greifswald. He has studied art history in Frankfurt, Marburg and Hamburg. His PhD thesis (1997 in Hamburg) was entitled Genealogie als Monument und Argument (Genealogy as Monument and Argument). For the period 1997-1999, he was a postdoctoral researcher at the Max Planck Institute for the History of Science in Berlin; 1999-2005 Scientific Assistant at the universities of Heidelberg and Frankfurt am Main. After his Habilitation 2009 on the works of painter Carl Blechen, Heck became the Chair of Art History at the University of 
Jena. In 2011, he was appointed as the Chair of General Art History at the Caspar-David-Friedrich-Institute at the University of Greifswald. Since 2013, Heck has been first chairman of the German Art Historian Association. Recent publications include: Schlösser und Gutshäuser in der Ostseeregion. Komponenten einer europäischen Kulturlandschaft (ed. by Kilian Heck, Jana Olschewski, 2017); Vergewisserung. Zur Rezeptionsgeschichte der Werke Carl Blechens (ed. by Kilian Heck, Beate Gohrenz, 2017). 